\title{
Keberhasilan Hukum Islam Menerjang Belenggu Kolonial dan Menjaga Keutuhan Nasional
}

\author{
Faiq Tobroni \\ E-mail : faiqtobroni@yahoo.com
}

The receptie exit theory of Hazairin has freed Islamic Law from legal colonization as a result of the receptie theory. Since the independence day, the receptie theory has not been effective any longer, because since then Pancasila has been the main source of laws, including Islamic Law, without any subordination. However, the inclusion of the word "Islam" in the previous Pancasila, known as Piagam jakarta, had been controversial. Nevertheless, Hatta had been successful to cope with the problem by substituting the controversial word in the first principle to the symbolic word of "Oneness" which remains to contain Islamic spirit. This choice has succeeded to defend Indonesian state integrity.

Keywords: receptie exit, receptie, colonization, state integrity.

\section{Pendahuluan}

$S_{n}^{\text {eos }}$ ebelum memasuki pintu kemerdekaan, hukum Islam mengalami perlakuan marginalisasi oleh pemerintah kolonial. Hukum Islam telah dirugikan teori receptie yang disponsori oleh Cornelis van Vollenhoven (1874-1993) dan kemudian diteruskan Cristian Snouck Hurgronje (1857-1936). Melalui teori ini, seolah-olah hukum Islam terletak inferior di bawah hukum adat. Penulis Barat/Belanda menggambarkan hukum Islam dan adat sebagai dua unsur yang bertentangan. Teori konflik yang mereka pergunakan untuk mendekati masalah hubungan kedua sistem hukum itu dengan sadar bertujuan untuk memecahbelah dan mengadu-domba rakyat Indonesia. Selanjutnya, rencana ini mempunyai target untuk mengukuhkan kekuasaan Belanda di tanah air ini.

Hazairin sangat gelisah dengan ulah teorinya Snouck ini. la merasakan sendiri bahwa teori ini hanyalah mainan Belanda untuk menjaga kekuasaannya aman di Indonesia. Teori dari Hazairin ini adalah teori receptie exit. Teori ini merupakan instrumen untuk mengembalikan kedudukan hukum Islam sebagai mitra hukum adat. Sebelumnya, menurut teori receptie, hukum Islam berada di bawah hukum adat. Di bawah teori receptie ini, hukum Islam mendapat segudang stigma negatif termasuk penyudutan kedudukan Islam sebagai pemecah belah keutuhan nasional. Dengan teori receptie exit ini, paling tidak, hukum Islam adalah mitra hukum adat untuk bersamasama membangun hukum nasional dalam wajah pluralitasnya. (Daud Ali, 1994)

Spirit Hazairin ini sebenarnya seirama dengan Hatta yang berhasil menggagas konstitusi yang menghargai keberagaman. Momen penetapan konstitusi mengisahkan adanya tarik-menarik antara merumuskan konstitusi yang beridentitaskan Islam 
UNISIA, Vol. XXXII No. 72 Desember 2009

ataukah sekedar substansialisasi Islam. Peristiwa ini seperti terekam saat perumusan Piagam Jakarta/Pancasila. Panitia kecil BPUPKI telah berhasil memasukkan unsur Islam: "dengan kewa-jiban menjalankan sjari'at Islam bagi pemeluknya"ke dalam pasal 1. Akan tetapi dalam rapat besar BPUPKI, Hatta mencoret 7 kata tersebut lalu menggantinya dengan "berdasarkan Ketuhanan Yang Maha Esa."

Apa yang bisa ditarik kesimpulan dari berbagai peristiwa hukum tersebut adalah kelihaian para pemikir hukum pada eranya masing-masing untuk mengedepankan inklusifisme hukum nasional daripada ekslusifisme. Artinya, sejak semula para ahli tidak menginginkan hukum nasional berdiri di atas satu kaki karakter hukum saja. Tidak dibangun di atas hukum Islam saja atau hukum adat saja. Pada akhirnya, Pancasila menjadi rumah bersama landasan yuridis bagi berlakunya hukum Islam dan hukum adat.

Di banding dengan penelitian yang telah ada, tulisan ini membawa dua keunggulan tujuan tersendiri. Pertama, penelitian ini akan menghasilkan temuan tidak hanya perdebatan teori saja. Di samping itu, hasilnya akan menggambarkan pergulatan politik di balik kristalisasi teori. Penelitian yang ada selama ini terjebak melihat perdebatan teori berhenti sekedar pertentangan teori. Melalui penelitian ini, teori receptie akan terbaca bahwa sebenarnya bertujuan melemahkan hukum menjadi tidak supreme, karena subordinate di bawah kepentingan politik kekuasaan penjajah.

Kedua, penelitian ini akan menghasilkan temuan tidak hanya perdebatan redaksi kata-kata Piagam Jakarta. Melebihi hal itu, hasilnya akan menggambarkan pemikiran cerdas Hatta dalam menjaga keutuhan persatuan bangsa Indonesia. Penelitian yang ada selama ini terjebak melihat penghapusan tujuh kata Islami sebagai pengkhianatan kepada Islam. Penghapusan ini justru akan terbaca bahwa sebenarnya redaksi penggantinya tetap berjiwa hukum Islam, yakni "keesaan".

Berdasarkan latar belakang masalah di atas, penulis mempunyai dugaan sementara bahwa pemerintah kolonial menganggap gerakan Islam mempunyai potensi menjadi gerakan melawan penjajah. Dengan demikian, jika keberlakuan hukum Islam dihentikan, maka masyarakat Islam akan kehilangan legitimasinya, yang dengan demikian akan mengakibatkan gerakan Islam mengalami kemandulan dalam memperkuat gerakan kemerdekaan.

Terkait dengan masalah redaksi bagi konstitusi, pemilihan karakter kata-katanya mempunyai signifikansi akibat yang serius. Simbolisasi Islam dalam konstitusi akan berakibat gangguan pada keutuhan bangsa Indonesia. Sebab konstitusi bertujuan melindungi melindungi semua elemen hukum yang hidup dalam negara Indonesia, maka susunan redaksinya harus mencerminkan semangat kebhinekaan.

\section{Kajian Pustaka}

Berdasarkan fokus penelitian yang diambil, maka saya berangkat dari beberapa buku yang cukup membantu untuk menghantarkan terlaksananya penelitian ini. Dari penelusuran pustaka yang saya lakukan, buku yang sesuai dengan bidang yang menjadi fokus kajian adalah sebagai berikut:

a. Ter Haar, Hukum Adat dalam Polemik IImiah (Jakarta: Bhratara, 1973).

b. Hazairin, Tujuh Serangkai tentang Hukum (Jakarta: Bina Aksara, 1981).

c. Sayuti Thalib, Receptio a Contrario: Hubungan Hukum Adat dengan Hukum Islam (Jakarta: Bina Aksara, 1980). 
Keberhasilan Hukum Islam Menerjang Belenggu Kolonial dan...; Faiq Tobroni

d. Ahmad Rofiq, Pembaharuan Hukum Islam di Indonesia (Yogyakarta: Penerbit Gama Media, 2001).

e. A. Qodry Azizy, Hukum Nasional; Eklektisisme Hukum Islam dan Hukum Umum (Jakarta: Penerbit Teraju, 2004).

f. Mohammad Hatta, Pengertian Pancasila (Jakarta: Idayu, 1977).

g. Muhammad Natsir, Islam dan Negara dalam Perspektif Islam (Jakarta: Penerbit Media Dakwah, 2001).

h. Endang Saifuddin Anshari, Piagam Jakarta 22 Juni 1945; Sebuah Konsensus Nasional tentang Dasar Negara RI (1945-1949) (Jakarta: Gema Insani Press, 1997).

i. Ahmad Syafi'i Maarif, Studi tentang Percaturan dalam Konstituante; Islam dan Masalah Kenegaraan (Jakarta: LP3ES, 1985).

\section{Metode Penelitian}

Penulis menggunakan metode penelitian sebagaimana teruraikan di bawah ini:

\section{Jenis Penelitian.}

Jenis penelitian yang dipergunakan dalam menulis karya ini adalah library research (penelitian pustaka), yaitu penelitian yang menggunakan karya tertulis sebagai sumber data dan sesuai dengan objek penelitian. (Kartini, 1996)

\section{Teknik Pengumpulan Data.}

Dalam penelitian ini, penulis menggunakan metode dokumentasi. Data primer yang penulis pergunakan berangkat dari karya Ter Har tentang Hukum Adat dalam Polemik IImiah, Hazairin tentang Tujuh Serangkai tentang Hukum dan Mohammad Hatta tentang Pengertian Pancasila. Sedangkan data primer yang penulis gunakan adalah buku-buku dari beberapa pemikir yang telah membahas tentang tema fokus penelitian.

\section{Teknik Menganalisis Data.}

Dalam menganalisa data, penulis menggunakan cara berpikir logis. (Hasan Bisri, 2003) Namun dalam penelitian ini, penulis hanya akan menggunakan salah satu cara berpikir logis, yaitu cara berpikir induktif. Cara berpikir induktif adalah cara berpikir yang berangkat dari fakta-fakta kasus dan kemudian dari fakta tersebut dihubungkan antara satu dengan yang lainnya sehingga ditarik dalam satu kesimpulan yang general. (Saifuddin, 1998) Metode ini digunakan untuk memaparkan pendapatpendapat yang bermacam-macam guna disatukan untuk mendapat pemaparan yang menyatu dan saling mendukung.

\section{Hasil Penelitian dan Pembahasan}

\section{Teori Receptio in Complexu}

Ada beberapa teori berlakunya hukum Islam di Indonesia. Yang pertama marilah kita mulai dengan teori yang dikemukakan oleh van den Berg yang dinamakannya receptio in complexu. Teori ini dikemukakan oleh Prof. Mr. Lodewijk Wilem Christian van den Berg (1845-1927). Teori ini berpendapat bahwa bagi orang Islam berlaku penuh hukum Islam karena dia telah memeluk agama Islam. Hukum yang berlaku bagi masyarakat Muslim adalah hukum Islam, meskipun bentuk hukum tersebut mengalami perbedaan di masing-masing daerah.

Pada zaman VOC, keberadaan hukum perdata Islam telah diakui pemerintah kolonial. Dengan diterbitkannya Regerings Reglement tahun 1885, keberadaan hukum yang telah ada diperkuat dan dikokohkan dengan pembentukan peraturan perundang-undangan. 
UNISIA, Vol. XXXII No. 72 Desember 2009

Pada saat itu banyak kerajaan Islam telah menerapkan hukum Islam serta mempunyai peradilan Islam sendiri-sendiri. Beberapa kerajaan Islam seperti Samudra Pasai, Kesultanan Demak, Kesultanan Mataram, Cirebon, Banten Kutai, Sumatra dll.

Dengan mengakui bahwa hukum yang berlaku bagi warga pribumi adalah hukum agamanya, ini menyebabkan VOC berkewajiban menyusun pelbagai pedoman hukum bagi pejabat pemerintah saat bertugas menyelesaikan urusan-urusan hukum rakyat pribumi. Di antara pedoman hukum yang terkenal adalah sbb:

1. Compendium Freijer yang merupakan kitab hukum kumpulan hukum perkawinan dan kewarisan Islam oleh pengadilan VOC.

2. Cirbonsch Rechtboek yang dibuat atas usul residen Cirebon.

3. Compendium der Voornaamste Javaansche Wetten nauwkeurig getrokken uit het Mohammedaansche Wetboek Mogharraer, dibuat untuk Landraad Semarang. (Sosro Atmojo, 1928)

Van den Berg berjasa atas penerbitan Stbl 1882 No. 152 yang isinya menyatakan bahwa yang berlaku bagi warga pribumi Islam adalah hukum agamanya. Sebagai akibatnya, di beberapa daerah berdirilah pengadilan Islam dengan berbagai nama seperti Mahkamah Syari'ah di Sumatra, Kerapatan Kadhi di Kalimantan, Majlis Syara' di Sulawesi, Maluku dan Irian.

Dengan demikian, teorinya van den Berg telah berjasa memberikan pemahaman yang menguntungkan bagi hukum Islam di mata pejabat dan para hakim Belanda. Dia juga berjasa mengenalkan karya hukum Islam kepada kesusasteraan Barat, yakni dia telah menerjemahkan kitab Fathul Qorib dan Minhajut Thalibin dari bahasa Arab menjadi bahasa Perancis.
Dalam kaitannya dengan hukum Islam, Reglement of het Beleid der Regering ven Nederlandsch Indie (RR) S. 1885 No. 2 menegaskan dalam pasal 75 dan 78 yang substansi isinya adalah sbb: a) Hakim Indonesia harus memberlakukan undangundang agama (godsdientige wetten) dan kebiasaan penduduk Indonesia itu; b) Undang-undang dan kebiasaan itu pulalah yang harus digunakan hakim Eropa saat memutus perkara di Pengadilan yang lebih tinggi andaikata terjadi pemeriksaan banding. Serta pasal 105 menyatakan bahwa ketentuan dalam pasal 75 dan 78 juga berlaku bagi orang yang dipersamakan dengan "Inlander", yaitu orang Arab, Moro, Cina dan semua mereka yang beragama Islam serta orang-orang yang tidak beragama (Suryaman, 1994)

\section{Teori Receptie}

Selanjutnya adalah teori receptie. Teori ini dilahirkan oleh Prof. Christian Snouck Hurgronje (1857) dan kemudian diteruskan C. Van Vollenhoven dan Ter Har Brn. Menurut teori ini, hukum yang berlaku bagi rakyat jajahan pribumi adalah hukum adat karena hukum Islam baru berlaku jika norma Islam telah diterima oleh masyarakat menjadi aturan adat. Teori ini sebagai penolak teori sebelumnya, yang sekaligus mengakibatkan berpindahnya pemegang wewenang penanganan masalah hukum di Hindia Belanda. Kalau berdasarkan teori sebelumnya, penyelesaian masalah perdatanya rakyat pribumi berada dalam kekuasaan pengadilan, maka karena teori ini beralihlah ke Landraad (Soepomo, 1963).

Keberadaan teori ini lebih bertendensi politik di banding dengan penemuan ilmiah. Teori ini dimaksudkan untuk mengurangi kesetiaan pribumi muslim memegangi ajaran Islamnya. Karena logikanya, kalau 
Keberhasilan Hukum Islam Menerjang Belenggu Kolonial dan...; Faiq Tobroni

masyarakat terlalu kental memperjuangkan positivasi hukum Islam maka mereka akan sulit dicekoki dengan ide dan hukum barat yang sebagai akibatnya akan menimbulkan guncangan terhadap kekuasaan pemerintahan Hindia Belanda. (Alfian, 1977) Apalagi dengan semakin mengakarnya perjuangan hukum Islam, dikhawatirkan pribumi muslim akan mudah kemasukan ide gerakan Pan Islamisme yang saat itu sedang hangat-hangatnya dikampanyekan Jamaluddin Al-Afghani.

Snouck sendiri bertugas di Indonesia (Hindia-Belanda) sebagai penasihat pemerintah Belanda. Menurutnya, kebijakan pemerintah kolonial yang menerbitkan Stbl. 1882 No. 152 yang dilandasi teori Receptio in Complexu adalah lahir dari ketidakmengertian pemerintah Hindia Belanda terhadap situasi masyarakat pribumi khususnya masyarakat Muslim. Menurutnya, selama ini teori tersebut tidak menguntungkan bagi pemerintah Hindia Belanda karena dari kesadaran beragama inilah justru lahir gerakan menentang penjajahan. Seperti meminjam ungkapan Deliar Noer "dapat dikatakan bahwa nasionalisme (yang sesungguhnya) di Indonesia dimulai dengan nasionalisme Muslim". (Deliar Noor, 1982)

Kemudian Snouck sebagai penasihat memberikan masukan kepada pemerintah kolonial untuk menerapkan "Islamic Policy." Beberapa isi dari kebijakan ini antara lain: a) Mengenai kegiatan agama dalam arti sebenarnya (agama dalam arti sempit), pemerintah kolonial harus memberikan peluang bagi mereka untuk beribadah sesuai dengan kemauannya; b) Pemerintah kolonial hendaknya menghormati adanya hukum adat dan membantu pengembangannya; c) Namun dalam bidang ketatanegaraan terdapat keharusan bagi pemerintah untuk mencegah gerakan Pan Islamisme. (Suryaman, tt.)

Terlihat dengan jelas bagaimana caranya Snouck menghantam agama dengan senjata adat. Dia menganjurkan pemerintah memberi peluang yang sebesarbesarnya akan pengembangan hukum adat, di samping itu memberi kesempatan sebesar-besarnya bagi pemeluk Islam namun hanya dalam melaksanakan ibadah yang mana dibalik itu terdapat hal yang merugikan dengan larangan masuknya ideide Islam dalam bidang ketatanegaraan terutama ide Pan Islamisme.

Langkah ini kemudian diteruskan dengan pemangkasan wewenang berlakunya sejumlah lapangan hukum agama. Seperti dihilangkannya keberlakuan hukum hudud dan qishash dalam masalah pidana. Salah seorang di antara master architect pembatasan wewenang Pengadilan Agama di Jawa dan Madura adalah Ter Haar. Menurutnya, antara hukum Adat dengan hukum Islam tidak mungkin bersatu, apalagi bekerja sama, karena titik-tolaknya berbeda. Hukum Adat bertitik-tolak dari kenyataan hukum dalam masyarakat, sedang hukum Islam bertitik-tolak dari kitab-kitab hukum. Karena itu, wewenang Pengadilan Agama di Jawa dan Madura, "dibatasi sampai ke bidang yang sekecil-kecilnya".

Jadi menurut teori receptie ini, hukum Islam tidak berlaku dalam masyarakat pribumi tapi yang berlaku adalah adat istiadat masing-masing. (Daud Ali, 1973) Dalam wujud peraturan, teori ini mulai diterapkan pada pasal 134 ayat (2) Indische Staatsregeling (IS) 1952 yang sama bunyinya dengan artikel pasal 78 R.R. 1855 dan R.R. 1907 dan R.R. 1919, yang berbunyi: "Dalam hal terjadi perkara perdata antara sesama orang Islam akan diselesaikan oleh hakim agama Islam apabila keadaan 
UNISIA, Vol. XXXII No. 72 Desember 2009

tersebut telah diterima oleh Hukum Adat mereka dan sejauh tidak ditentukan lain oleh ordonansi. (Sadzali, tt.)

\section{Teori Receptie Exit}

Selanjutnya adalah teori receptie exit. Teori ini dikembangkan oleh Prof. Dr. Hazairin, S.H. Teori ini merupakan penentang bagi teori receptie. Menurutnya, setelah bangsa Indonesia mencapai kemerdekaannya, serta setelah disahkannya pembukaan dan batang tubuh UUD 1945, meskipun dalam peraturan peralihan dinyatakan, bahwa hukum sebelum proklamasi masih diperbolehkan keber-lakuannya, maka dengan sendirinya teori receptie telah kandas berlakunya.

Teori ini harus exit karena bertentangan dengan UUD 1945 serta merupakan teori iblis karena bertentangan dengan Allah dan rasul-Nya. (Hazairin, 1981) Logikanya, setelah menyatakan kemerdekaannya, bangsa Indonesia bebas melaksanakan hukumnya tanpa terkekang oleh peraturan dan teori konstitusi Belanda (Indische Staatsregeling) karena pemberlakuan norma-norma agama ini juga mendapat pijakan yang eksplisit langsung dari pembukaan maupun batang tubuh UUD 1945.

Dasar semakin menguatnya akan pemangkasan teori receptie ini adalah alinea ketiga pembukaan UUD yang menyatakan bahwa kemerdekaan bangsa Indonesia dapat tercapai karena atas berkat rahmat Allah yang Maha Kuasa. Dengan demikian, alinea ini memberi pesan bahwa kehidupan bernegara bangsa Indonesia sangat dijiwai Ketuhanan. Di samping itu, kesadaran menjalankan hukum Islam bukan karena bila hukum Islam telah disetuji hukum adat, tapi keinginan melaksanakannya sudah merupakan kesadaran batin untuk melak- sanakan syukur yang diberikan Allah melalui bentuk kemerdekaan ini.

Sedangkan mengenai perubahan yang menimpa kata-kata syari'at Islam dalam pembukaan dan batang tubuh UUD 1945, yang penggantiannya menjadi atas "Ketuhanan Yang Maha Esa", menurutnya hal ini bukanlah menandakan penyingkiran hukum agama dari pembangunan hukum nasional. Justru dengan perubahan itu telah menunjukkan adanya pemberian kesem-patan yang sebenar-benarnya bagi pelaksanaan hukum agama. Di mana bagi orang Islam dibolehkan menerapkan hukum Islam, serta bagi pemeluk agama lainnya dibolehkan melaksanakan hukum agamanya masing-masing.

Selanjutnya teori receptio a contrario. Sayuti Thaliblah yang mengembangkan teori ini, yang merupakan penjabaran dari teori receptie exit. Teori ini meneguhkan kembali bahwa bagi orang Islam berlaku hukum Islam. Hukum Adat boleh berlaku kalau tidak bertentangan dengan hukum Islam. (Sayuti, 1980)

Perjuangan menerjang belenggu teori receptie secara prinsipal menampakkan hasilnya dengan terbitnya UUD 1945. Sebab, sudah sangat jelas dan tegas ketentuan yang ada di dalam Pembukaan UUD 1945 dan dalam pasal 29 pada Batang Tubuhnya. Secara instrumen undangundang, teori ini sampai ajalnya dengan terbitnya UU No. 1/1974 tentang Perkawinan. Undang-undang ini diakui sangat kental berjiwa Islam.

Sebenarnya niat baik memangkan teori receptie melalui realisasi instrumen lembaga peradilan telah ada tahun 1957. Instrumen tertulis dalam PP No. 45 tentang Pembentukan Pengadilan Agama/Mahkamah Syar'iyah di Luar Jawa dan Madura dengan nama Pengadilan Agama/Mahkamah Syariah di tingkat pertama dan 
Keberhasilan Hukum Islam Menerjang Belenggu Kolonial dan...; Faiq Tobroni

Pengadilan Agama/Mahkamah Syariah Provinsi di tingkat banding (Lembaran Negara tahun 1957 No. 99). Akan tetapi dalam PP ini masih secara eksplisit memuat rumusan tentang jaminan "pilihan hukum".

Sebagai akibatnya, para pencari keadilan mempunyai kebebasan untuk memilih berperkara di Pengadilan Agama atau di Pengadilan Negeri. Kemandulan ini baru terputus dengan lahirnya UU. No. 7 tahun 1989 tentang Peradilan Agama (UUPA). Dengan terbitnya UU ini, umat Islam yang akan menyelesaikan perkara perdatanya harus ke Pengadilan Agama. (Azizi, 2004)

\section{Hukum Islam Membebaskan Diri dari Belenggu Kolonial}

Dari tarik-menarik pengakuan teori berlakunya hukum, sebenarnya letak duduk persoalan utamanya adalah masalah kekuasaan (power). Muatan pokok teori receptie ini adalah prinsip divide at impera yang bertujuan untuk menghambat dan menghentikan meluasnya Hukum Islam dan membentuk konsep hukum tandingan yang mendukung politik pecah belah pemerintah kolonial (Rofiq, 2001)

Hukum sebenarnya hanya ditempatkan sebagai alat untuk mencapainya. Dalam bahasa ushul fiqh adalah 'al-amru bi al-sya' amrun bi al-wasâilihi', yakni upaya untuk mendapatkan sesuatu menyaratkan upaya melengkapi sarana-prasarananya. Hukum menjadi sarana untuk mendukung dan menguatkan kekuasaan yang menjadi target tujuan. Snouck mengkampanyekan teori receptie, yang kelihatannya melalui teori ini pemerintah kolonial memberi perhatian kepada hukum adat. Sebenarnya bukan hukum adatlah yang ingin dikuatkan, melainkan ini hanyalah sekedar cara untuk memalingkan masyarakat pribumi dari hukum Islam. Kemudian setelah berhasil maka tinggal membelokkannya untuk mendekat kepada ide-ide Barat, yang tentu saja diharapkan hasilnya akan memperkuat posisi Belanda menjadi penjajah.

Sementara itu Hazairin dan Sayuti Thalib hendak mengembalikan kesadaran bangsa Indonesia untuk melawan kolonial termasuk melalui penolakan teori receptie. Untuk langkah itu digunakanlah Islam, yang memang dalam pembukaan UUD 1945 telah mengakui bahwa atas rahmat dan spirit Ketuhananlah bangsa Indonesia menyatakan kemerdekaannya.

\section{Konstitusi Islam yang Bernafaskan Keindonesiaan}

Pada tanggal 24 April 1945, Jepang menyeponsori pembentukan Dokuritsu Syumbi Tyoosakai (Badan Penyelidik Usaha Persiapan Kemerdekaan Indonesia/BPUPKI). Badan itu melaksanakan sidang pertamanya tanggal 29 Mei sampai 1 Juni 1945.

Segera setelah selesainya sidang yang pertama, beberapa anggota membentuk panitia kecil yang terdiri atas sembilan orang yaitu: Soekarno, M. Hatta, A.A. Maramis, Abikusno Tjokrosujoso, Abdul Kahar Muzakkir, H. Agus Salim, Ach. Soebarjo, A.W. Hasjim dan M. Yamin. Setelah melalui likaliku pembicaraan serius, panitia kecil ini berhasil mencapai satu modus vevendi. Kesepakatan ini menjadi penerimaan bersama antara para nasionalis Islam di satu pihak dan para nasionalis sekuler di pihak lain. Kesepa-katan inilah yang kita kenal dengan rumusan untuk preambule Undangundang Dasar yang kemudian dikenal dengan Piagam Jakarta.

The Jakarta Charter ini kemudian ditandatangani oleh kesembilan perumus tanggal 22 Juni 1945. Mengenai muatan 
yang menimbulkan kontroversi terletak pada paragraf terakhir dalam hal dasar negara yang berpijak pada: "Ketuhanan, dengan kewajiban menjalankan sjari'at Islam bagi pemeluknya". (Yamin, 1950) Setelah dibawa ke sidang pleno BPUPKI kedua yang berlangsung tanggal 10-16 Juli 1945, muatan tersebut memancing perdebatan.

Salah satu tokoh yang berasal dari agama Protestan, yang bernama Latuharhary, menolak anak kalimat tersebut. Dia beralasan bahwa rakyat Indonesia yang hidup di wilayah Indonesia timur tidak menyetujui hal tersebut. Mereka yang bukan kaum Muslim merasa keberatan tetap bergabung dalam negara kesatuan Republik Indonesia jika konstitusinya tidak mengakomodir semangat kebhinekaan. Sedangkan Ki Bagus Hadikusumo dari kelompok Muslim bahkan lebih ganas lagi meminta penghilangan kata-kata "bagi pemeluknya." (Suryaman, tt.)

Kalau permintaan ini diikuti, maka lebih fatal lagi sebab konstitusi akan memutlakkan perintah menjalankan kewajiban syari'at Islam bagi siapapun orangnya. Lalu Soekarno sebagai juru bicara dari panitia sembilan ini menyatakan bahwa isi tersebut merupakan gentleman's agreement antara kaum nasionalis sekuler dan agamis sehingga keberadaannya merupakan buah pikiran yang tidak mungkin sepihak.

Karena kuatnya kemauan panitia sembilan mempertahankan dan rasionalitasnya argumen bahwa hasil itu merupakan hasil kompromi, maka Radjiman Wedyodiningrat sebagai Ketua Badan Penyelidik memberi masukan yang intinya menanyakan apakah untuk menyelesaikan masalah kontroversial tersebut apakah perlu diperlukan pemungutan suara. Lalu dia meneruskan, dengan alasan karena ini sudah merupakan hasil kompromi yang telah menggaransikan take and give antara kedua belah pihak, maka harus dilanjutkan terjalinnya persatuan dengan tidak menunjukkan keterpecahan.

Pada tanggal 17 Agustus 1945, dengan mengatasnamakan Bangsa Indonesia, Soekarno-Hatta memproklamasikan kemerdekaan Indonesia. Karena desakan yang begitu kuat untuk meninjau ulang isi pembukaan UUD 1945, keesokan harinya Panitia Persiapan Kemerdekaan Indonesia mengadakan rapat membahas perubahan pembukaan UUD 1945. Pada pertemuan inilah telah terjadi sejarah yang sangat penting dalam perubahan pendahuluan UUD 1945.

Hatta dipersilahkan menyampaikan empat poin perubahan, yakni: 1) "Mukaddimah" diganti "Pembukaan"; 2) kalimat "Berdasarkan kepada Ketuhanan, dengan kewajiban menjalankan sjari'at Islam bagi pemeluknya" diganti menjadi "Berdasarkan Ketuhanan Yang Maha Esa"; 3) pasal 6 ayat 1 "Presiden ialah orang Indonesia asli dan beragama Islam," kata-kata "dan Beragama Islam" dicoret; serta 4) perubahan pasal 29 ayat 1 "Negara berdasarkan Ketuhanan Yang Maha Esa" sebagai ganti "Negara berdasarkan Ketuhanan dengan kewajiban menjalankan syari'at Islam bagi pemelukpemeluknya." (Sanusi, 1965)

Yang perlu dicatat dalam perubahan ini adalah, bahwa empat orang dari penandatangan Piagam Jakarta-lah yang ditunjuk dan dipilih sebagai anggota Panitia Persiapan Kemerdekaan, yaitu Soekarno, Hatta, Subardjo dan Wahid Hasjim. Di sisi lain, Wahid Hasjim (yang berasal dari pihak nasionalis Islam) sedang tidak berada di Jakarta pada saat perubahan tersebut. Dengan demikian, praktis hanya tiga orang yang terlibat dalam penghilangan "kalimat Islami" dari Undang-undang Dasar 18 
Keberhasilan Hukum Islam Menerjang Belenggu Kolonial dan...; Faiq Tobroni

Agustus 1945; ketiga-tiganya kelompok nasionalis sekuler.

Perubahan drastis tersebut diterima dengan lapang dada oleh kelompok sekuler, namun tetap menyisakan kekecewaan di hati kalangan agamis. Seperti sejalan dengan masalah antara hubungan agama dan negara tersebut, pada tahun 1940-an terjadi pula polemik perdebatan ideologi antara Soekarno dan Natsir. Soekarno sebagai juru bicara nasionalis sekuler menulis beberapa artikel dalam Pandji Islam tentang hubungan antara agama dan negara. Misalnya, judul tulisan Soekarno seperti: 'Memudakan Pengertian Islam,' 'Masyarakat Unta dan Masyarakat KapalUdara' dan 'Apa Sebabnya Turki Memisahkan Negara dari Agama.'

Menurut Soekarno, berdasarkan tulisan tersebut, kurang lebih membawa pesan akan perlunya Muslim Indonesia membedakan antara elemen Ketuhanan dan elemen kemanusiaan. Seperti, agama adalah ajaran yang suci berasal dari Tuhan, sementara negara adalah elemen profan yang tata cara pengelolaannya diserahkan kepada masingmasing pelaku sesuai dengan letak georafi dan latar belakang budayanya sendiri. (Soekarno, 1959) Di sisi lain, dengan adanya kebebasan mengelola negara sesuai karakter lokalnya sendiri-sendiri, diharuskan ada komitmen negara untuk tetap menjaga amannya kehidupan agama.

Kemudian Natsir menaggapi tulisantulisan Soekaro dengan satu sesi yang terdiri atas sembilan artikel berjudul "Persatuan Agama dan Negara." M. Natsir sebagai ketua Umum DPP Masjumi, dalam pidatonya dalam sidang pleno Konstituante tanggal 12 Nopember 1957 mengutarakan idenya untuk mendirikan negara Republik Indonesia berdasarkan Islam, yakni "Negara Demokrasi berdasarkan Islam". (Natsir,
2001) Kurang lebih menurut Natsir, Islam adalah agama yang mengurusi segala kehidupan manusia. Sebagai konsekuensinya, negara pun menjadi objek pengaturan agama. Akhirnya, tidak bisa dihindarkan lagi untuk mencapai kemakmuran, Indonesia harus berdasarkan Islam.

\section{Ketuhanan yang Esa; Spirit Pancasila ala Hatta yang Religius}

Pandangan Hatta tentang Pancasila dibentuk dan dipengaruhi secara dalam oleh pemahamannya terhadap ajaran-ajaran dasar Al-Qur'an. Dengan ungkapan lain, Pancasila Hatta lebih masuk akal keislamannya daripada tafsiran-tafsiran yang diberikan oleh seorang sekularis, agnostik atau apalagi seorang komunis. Pancasila Soekarno lebih bercorak sosiologis dan dalam bentuk aslinya menempatkan sila kebangsaan Indonesia sebagai sila pertama. Lebih jauh bagi Soekarno, kelima sila itu dapat diperas menjadi eka sila, yaitu gotong royong. Bagi Hatta, sila Ketuhanan yang Maha Esa menjadi dasar yang memimpin sila-sila yang lain. (Syafi'ie, 1985)

Justifikasi gotong royong dianggap sebagai satu sila yang mencakup kelima sila dalam Pancasila, jelas tidak dapat diterima oleh para pemuka Islam yang memandangnya sebagai ancaman bagi segisegi ajaran Islam yang amat fundamental. Menurut Roem, sebagaimana dikutip Endang, sila Ketuhanan Yang Maha Esa tidak dapat dihilangkan atau diselipkan dalam "gotong royong" bagi orang-orang yang memandang agamanya dengan sungguhsungguh. (Endang, 1997)

Penonjolan aspek Islam dengan hanya menempati aspek substansial dalam konstitusi negara ini sebenarnyalah mempunyai makna berharga. Mungkin masih 
UNISIA, Vol. XXXII No. 72 Desember 2009

maraknya kekakuan mendirikan negara Islam adalah disebabkan karena kurang siapnya menangkap Islam menjadi satu kesatuan jalan hidup. (Yudian, 2007) Setidaknya salah satu upaya memaknai Islam sebagai kesatuan cara hidup yang menyatu, menurut Prof. Yudian, telah dipraktekkan Hatta dalam mengibarkan kata "Ketuhanan Yang Maha Esa."

Dengan langkah ini, Hatta menghantam komunisme sejak dini, tetapi sekaligus mengibarkan bendera Tauhid. Hatta menyeimbangkan antara kepentingan agama dengan tetap terjaganya kesatuan tanah air. Di sinilah makna strategis konstitusional Hatta. Sila Ketuhanan Yang Maha Esa, sesuai dengan langkah Hatta, sudah mengakomodir Tauhid bagi umat Islam (sehingga wajar jika ia didaulat sebagai Bapak Pemersatu Konstitusional ketika mengganti tujuh kata dari Pancasila, yang kemudian dimasukkan kembali ke dalam Piagam Jakarta, dengan "Yang Maha Esa" sebagai pilihannya). Tujuh kata itu, bagi Hatta, adalah gincu: tampak tapi tidak berpengaruh. Sebaliknya, "Yang Maha Esa" adalah garam, karena tidak memamerkan identitas Islam tetapi sangat berpengaruh.

Sila Ketuhanan Yang Maha Esa, menurut Hatta, merupakan prinsip pembimbing bagi cita-cita kenegaraan di Indonesia. Prinsip spiritual dan etik ini memberikan bimbingan kepada semua hal yang baik bagi rakyat Indonesia. Sejalan dengan prinsip fundamen ini, sila kedua, sila ketiga, sila keempat dan sila kelima merupakan kelanjutan dari sila pertama dalam praktek. Dengan berpegang teguh kepada filsafat ini, pemerintah Indonesia jangan sampai menyimpang dari jalan lurus bagi keselamatan negara dan masyarakat, ketertiban dunia dan persaudaraan antara bangsa. Ditambah lagi, melalui sila yang pertama, negara memperoleh landasan moral yang kukuh. (Syafiie, 1997)

\section{Penutup}

Hukum haruslah objektif. la tidak boleh memihak si A untuk menindas si B. Segaris dengan prinsip ini, teori tentang keberlakuan hukum juga harus netral dan bebas kepentingan baik politik, ekonomi maupun kekuasaan. Pendestorsian teori keberlakuan hukum ini telah terjadi saat van Vollenhoven dan Snouck memunculkan teori receptie. Dengan teori ini, keberlakuan hukum Islam baru bisa dikatakan sah jika telah diserap, diterima dan tidak bertentangan dengan hukum Adat.

Menyelidiki motif teori ini, para pakar hukum di Indonesia menemukan teori ini syarat mengandung kepentingan politis. Teori ini untuk memandulkan berlakunya hukum Islam karena memiliki potensi bertentangan dengan hukum Belanda. Potensi ini bisa berimbas dengan munculnya kesadaran mendeligitimasi pemerintahan kolonial. Belanda membaca gejala ini sehingga menggunakan sarana hukum Adat untuk menghadang hukum Islam.

Dampak psikologis teori receptie ini sangat kuat hingga membutuhkan banyak perangkat hukum untuk menghentikannya. Secara prinsipil, teori ini telah dibendung melalui terbitnya Pembukaan UUD 1945 dan pasal 29 batang tubuhnya. Berdasarkan pembukaan telah dinyatakan, bahwa pengisian kemerdekaan ini secara non-fisik juga membutuhkan instrumen ajaran agama dalam membangun hukumnya. Selanjutnya pasal 29 menyatakan bahwa negara menjamin hak asasi bagi setiap orang menjalankan ajaran agamanya, baik dalam hal ibadah maupun hukumnya.

Upaya dalam menciptakan instrumen lembaga peradilan juga telah diupayakan 
Keberhasilan Hukum Islam Menerjang Belenggu Kolonial dan...; Faiq Tobroni

dengan lahirnya PP No. 45 1975. Akan tetapi sejauh menggunakan dasar ini, masyarakat muslim yang masih mengidap receptie menggunakan hak pilih hukumnya untuk berperkara di Pengadilan Negeri atau Pengadilan Agama dalam masalah perdata. Akhirnya beban ini telah tuntas dengan terbitnya UU. No. 7 tahun 1989 tentang Peradilan Agama yang mengatur bahwa untuk orang Islam mencari keadilan di Pengadilan Agama dalam masalah perdatanya.

Di sisi lain, Islam juga telah berjasa menjaga keutuhan Indonesia dalam perumusan konstitusi. Pada saat perumus-an Piagam Jakarta, sempat terjadi perde-batan terkait redaksinya; antara formalisasi Islam ataukah susbstansialisi Islam. Gejala formalisasi telah nampak dengan pencantuman tujuh kata Islam dalam sila I Pancasila. Pilihan ini mendapat reaksi keras sampai ada ancaman rakyat Indonesia Timur yang tidak beragama Islam enggan bergabung dalam NKRI.

Polemik ini akhirnya bisa diselesaikan Hatta yang telah mencoret tujuh kata tersebut dengan ganti redaksi "Ketuhanan Yang Maha Esa". Keesaan ini meskipun melambangkan redaksi yang bisa diterima oleh agama lain, sebenarnya masih sejalan dengan spirit Islam yakni Tauhid (monotheisme). Dengan demikian, Hatta telah berhasil menjaga kesatuan bangsa tanpa harus menghilangkan substansi ajaran Islam. Pancasila yang diidealkan Hatta juga memusatkan jiwanya pada sila pertama. Menurutnya, perjalanan kehidupan negara ini mempunyai pegangannya dengan landasan spiritual ketuhanan.

Pelajaran berharga ini sudah seharusnya diteruskan oleh para ahli hukum sekarang. Pembentukan undang-undang untuk masa sekarang ini juga masih diliputi nuansa penjajahan namun dengan wajah yang baru. Di antar modusnya adalah slogan liberalisme, kapitalisme, pasar bebas dll. Contoh ini sekedar tantangan dari eksternal, sementara di dalam internal sendiri juga mengalami banyak tantangan. Di antaranya adalah munculnya gerakan separatis.

\section{Daftar Pustaka}

Alfian (Editor), Segi-segi Sosial Budaya Masyarakat Aceh.Jakarta: LP3ES, 1977).

Ali, Mohammad Daud,1994, Hukum Islam; Pengantar IImu Hukum dan Tata Hukum Islam di Indonesia, Jakarta: Raja Grafindo Persada.

Anshari, Endang Saifuddin,1997. Piagam Jakarta 22 Juni 1945; Sebuah Konsensus Nasional tentang Dasar Negara RI (1945-1949), Jakarta: Gema Insani Press.

Azizy, Qodry, 2004.Hukum Nasional; Eklektis-isme Hukum Islam dan Hukum Umum.Jakarta: Penerbit Teraju.

Azwar, Saifuddin,1998. Metode Penelitian, cet ke-1,Yogyakarta: Pustaka Pelajar.

Bisri, Cik Hasan,2003. Model Penelitian Fiqh Jakarta Timur: Kencana.

Haar, Ter, 1973. Hukum Adat dalam Polemik IImiah,Jakarta: Bhratara.

Hatta, Mohammad,1977. Pengertian Pancasila, Jakarta: Idayu. 
UNISIA, Vol. XXXII No. 72 Desember 2009

Hazairin, 1981.Tujuh Serangkai tentang Hukum,Jakarta: Bina Aksara.

Kartono, Kartini,1996. Pengantar Metodologi Riset Sosial,Bandung: Mandar Maju.

Maarif, Ahmad Syafi'i,1985. Studi tentang Percaturan dalam Konstituante; Islam dan Masalah Kenegaraan Jakarta: LP3ES.

Natsir, M., 2001.Agama dan Negara dalam Perspektif Islam,Jakarta: Penerbit Media Dakwah.

Noer, Deliar,1982. Gerakan Modern Islam di Indonesia,Jakarta: LP3ES.

Notonagoro,1956. Pemboekaan Oendangoendang Dasar 1945,Yogyakarta: Ttp.

Rofiq, Ahmad,2001. Pembaharuan Hukum Islam di Indonesia, Yogyakarta: Penerbit Gama Media.

Sanusi, Ahmad,1965. Islam, Revolusi dan Masyarakat,Bandung: Sumur Bandung.
Soekarno,1959. Di Bawah Bendera Revolousi,Jakarta: Panitia Penerbit DBR.

Soepomo, 1963.Bab-bab Hukum Adat Jakarta: Penerbit Universitas.

Sosroatmodjo, 1928. Arso dan Wasit Aulawi, Hukum Perkawinan di Indonesia Jakarta: Bulan Bintang.

Surjaman, Tjun (ed),1994. Hukum Islam dalam Perkembangan dan Pembentukan,Bandung: Remaja Rosdakarya.

Thalib, Sayuti,1980. Receptio a Contrario: Hubungan Hukum Adat dengan Hukum Islam, Jakarta: Bina Aksara.

Wahyudi, Yudian, 2007,Maqashid Syari'ah dalam Pergumulan Politik Yogyakarta: Pesantren Nawesea Press.

Yamin,1950. Naskah Persiapan UndangUndang Dasar 1945,Jakarta: Yayasan Prapanca. 